\title{
Accelerated expansion of NATO into the Balkans as a consequence of Euro-Atlantic Discord
}

\author{
S. Gajić, E. Ponomareva \\ Institute of European Studies, Belgrade, Serbia \\ Moscow State Institute of International Relations (University)
}

The Balkans in general and post-Yugoslav countries in particular have been under significant geopolitical pressure of the political West since the end of the bipolar global order. From the beginning of the Yugoslav Civil War in 1991, followed by Western recognition of secessionist republics in 1992 and NATO attacks on Serbs in Bosnia-Herzegovina in 1994-1995 and on the Federal Republic of Yugoslavia in 1999, the US, NATO and EU have been actively involved in the Balkan crisis. It was in concordance with the logic of unipolarity, or the New World Order, proclaimed by George W.H. Bush, in which there is "no substitute for American leadership".

The year of 2008 marked the start of profound changes. The changes we are witnessing today are of the magnitude described by Paul Kennedy's classic The Rise and Fall of the Great Powers. Georgia's attack on South Ossetia crossed Russia's red lines and exposed the latter's ambitions to regain the superpower status; China symbolically showed the same ambition with the Olympics in Beijing; the crash of the US real-estate market triggered the global economic crisis; and the NATO-sponsored unilateral declaration of secession by Kosovo Albanians set a precedent and introduced uncertainty in international law and the entire system of United Nations. By the beginning of 2020, many problems had accumulated in the EU - against the background of the ongoing migration crisis, right-wing and nationalist movements became more active, and differences between members increased. Long before COVID-19, Brexit became a serious stress test for the economy and social structure of the European Union. Dramatic changes took place on the other side of the Atlantic too, resulting in the shocking victory of staunch anti-globalist Donald Trump. The rules established during the 1991-2008 unipolarity have thus been challenged. Subsequently, post-Cold War ideological consensus in the West has also been challenged even further by the growth of non-systemic political movements - many of them directed not only against the EU expansion, but also against the EU itself.

The significance of all these events for the Balkans is somewhat surprising and paradoxical, as the mainstream forces that have been weakened in the West forcefully push for a stronger Atlantic integration of the remaining Balkan countries. At the height of the pandemic, on 27 March 2020 Northern Macedonia became the 30th member of the Alliance, having previously undergone a humiliating procedure of changing its own name for this purpose. Three years earlier, Montenegro was admitted to NATO, but its population did not have the opportunity to vote on this in a referendum. The negotiations between Belgrade and Pristina on 'normalisation of relations', continued pressures on the prerogatives of Republic Srpska, Croatian initiative for a new Intermarium 
and many other similar efforts are stages in the process of NATOisation of former Yugoslavia. Based on the analysis of a large body of narrative sources and recent literature, the article presents the main trends and possible prospects for developments in the Balkans, depending on the outcome of the ongoing ideological and political struggle within the West.

Key words: Balkans, expansion of NATO, Russia, Serbia, Serbs, EU, Albanian question

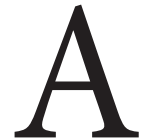

large body of academic literature exits on the question of NATO expansion in the Balkans (Borinski 2002; Cascone 2010; Mulchinock 2017). Because of the breakup of Yugoslavia and subsequent events, much was written over the last three decades alone. Names such as John R. Lampe (2013), Kenneth Morrison (2017), Nenad Kecmanović (2010), Aleksandar Raković (2017), Dejan Jović (2018), Slobodan Antonić (1997) are only tip of the iceberg among the authors who dedicated their work to this topic.

The paper aims at making sense of the accelerated NATO enlargement throughout the region in the last years, which is why the sources are not constrained to the ones that are strictly academic. This paper is also trying to identify whether there is a connection between NATO enlargement and rapid deterioration of the ideological consensus in what we could colloquially call the Political West and academically Euro-Atlantic community.

We attempt to show how the loss of ideological and political consensus in the Euro-Atlantic community reflects in the Balkans, as well as how it actually results in a push by NATO to integrate the remaining countries. Negotiations on the Kosovo issue is central for the future of the whole region, which is why it is given special attention in the article. The drive that led to integrating other countries, such as Montenegro and Northern Macedonia, and political processes in Croatia and Bosnia-Herzegovina are also described and explained in the context of transatlantic relations. In the final part of the paper we attempt to zoom out the perspective from the Balkans and show a broader picture in which the motivation of NATO is explained by connecting it with events that contribute to increasing divisions within the political West.

\section{Drawing the borders}

In 2016, former British diplomat Timothy Less was the first to start juggling with the idea of 'correcting the borders' ${ }^{\text {' }}$ in the Balkans, as can be seen in his essay published

\footnotetext{
1 "In the short term, Washington should support the internal fragmentation of multi-ethnic states where minorities demand it - for example, by accepting the Albanians' bid for the federalisation of Macedonia and the Croats' demand for a third entity in Bosnia. In the medium term, the United States should allow these various territories to form close political and economic links with their larger neighbours, such as allowing dual citizenship and establishing shared institutions, while formally remaining a part of their existing state" (Less 2016).
} 
in Foreign Affairs, which created quite a stir in the Balkans and elsewhere. Less argued that the current borders should be adjusted to match the ethnic map of the region.

"In the final phase, these territories could break from their existing states and unite with their mother country, perhaps initially as autonomous regions. A Croat entity in Bosnia would merge with Croatia; Republika Srpska and the north of Kosovo with Serbia; and the Presevo Valley, western Macedonia, and most of Kosovo with Albania. Meanwhile, Montenegro, which may lose its small Albanian enclaves, could either stay independent or coalesce with an expanded Serbia" (Less 2016).

Following Less, other influential figures endorsed the idea and promoted it in one form or another. They include former UK Prime Minister Tony Blair, Alexander Soros (the son of the ageing philanthropist George Soros), Robert Cooper (retired senior British diplomat, famous for his book Breaking of Nations: Order and Chaos in the Twenty-First Century (Cooper 2004), sort of a manifesto for the global dominance of the West), Federica Mogherini (then-High Representative of the European Union for Foreign Affairs and Security Policy), Mathew Palmer (US State Department special representative for the Western Balkans ).

This idea has also been acceptable for certain Balkan leaders, even to the point of jeopardising their own position within their voting pools. The question is: why? What motivates politicians to pursue an unpopular idea, with a zeal that damages their public image in general, and do it even in their own constituencies? Whatever their motivation might be, the most important among these leaders are Serbian President Aleksandar Vučić, President of the Kosovo Provisional Institutions of Self-Government Hashim Thaçi, and the Albanian Prime Minister Edi Rama. While these three are directly involved parties, other Euro-Atlantic enthusiasts of the region, such as Macedonian Prime Minister Zoran Zaev or Montenegrin President Milo Đukanović, were somewhat ${ }^{2}$ or completely reserved ${ }^{3}$ about the idea. Judging by the public conduct of the top officials, it appears that the leading external actors behind the process are $\mathrm{NATO}^{4}$ and the former leadership of the European Commission, represented by Mogherini ${ }^{5}$ who was leading the Brussels negotiating process and trying to broker a deal with Vučić and Thaçi are the main driving force.

The essence of the deal (which will be called 'NATO deal' in this article, for reasons soon to be elaborated) was meant to be the exchange of territories between Serbia and its disputed province of Kosovo and Metohija. According to the plan, Serbia was supposed to agree on independence of Kosovo in exchange for territorial compensa-

\footnotetext{
2 Montenegrin president says Kosovo issue European security problem. URL: http://rs.n1info.com/English/NEWS/ a490203/Montenegrin-president-says-Kosovo-issue-European-security-problem.html (accessed 29.03.2020).

3 Zaev Says Russia Influenced Vučić-Thaçi Negotiations Over Territorial Swap. URL: https://exit.al/en/2019/07/10/zaevsays-russia-influenced-vucic-thaci-negotiations-over-territorial-swap/ (accessed 25.03.2020).

4 Haxhiaj S. 2019. NATO Admiral: Compromise Needed for Kosovo-Serbia Deal. Balkan Insight. URL: https://balkaninsight. com/2019/05/24/nato-admiral-compromise-needed-for-kosovo-serbia-deal/ (accessed 30.03.2020).

${ }_{5}$ Barigazzi J. 2019. Mogherini defends Kosovo border change talks. Politico. URL: https://www.politico.eu/article/federicamogherini-kosovo-serbia-defends-border-change-talks/ (accessed 15.04.2020).
} 
tion through four municipalities in the north of the province predominantly inhabited by Serbs that would get fully reintegrated into the Serbian state (Ponomareva 2020). It was speculated that Serbia would cede to Kosovo the municipality of Preševo and parts of two neighbouring municipalities of Bujanovac and Medveđa. The crown of this deal would be a "legally binding agreement ensuring full mutual recognition as two independent and sovereign states"6.

Formally, such land swap would be unconstitutional on both sides. Serbia's constitution sees the province in its entirety a part of Serbia, so negotiating giving away any part of it is directly against the legal foundation of the country and a punishable crime of high treason. Ironically, even the very Kosovo constitution considers such territorial adjustments a crime, making both Vučić and Thaçi responsible for high treason, which was brought to their and public attention numerous times, by different parties. Vučićs strongest opposition came from the Serbian Orthodox Church which opposes the secession for many reasons, most importantly because the province is home to churches and monasteries of immeasurable spiritual and historical significance, some dating back to the 12th century, including the Peć Patriarchy monastery, the historical seat of Serbian Patriarchs. In addition to the Church, Vučićs idea is opposed by the vast majority of population, including numerous public intellectuals and the vast majority of the opposition political parties.

So why would the Serbian President follow a path that blatantly conflicts with the constitution which he swore to uphold? What is of higher value for any head of state than the highest law of the country? The answer may be found in his choice of closest advisors and allies: Tony Blair, Alexander Soros and Mohammed Bin Zayed Al Nahyan, the Crown Prince of Abu Dhabi. "Now Vucic and Blair find themselves on the same side under a contract sealed by Blair's private consultancy to set up a 'delivery unit' paid for, according to Serbian official sources, by the United Arab Emirates". Similarly, Thaçi is facing enormous opposition and even parts of the government ${ }^{8}$ are against his plan which he calls 'border correction'.

Rama and NATO supported the plan hoping that after the agreement, independent Kosovo would eventually join Albania, a NATO member, thus creating Greater Albania'. In such a case, the territory of Kosovo would automatically be part of NATO. On the other hand, the plan would render obsolete the UN Security Council Resolution 1244, which guarantees Serbia's sovereignty over Kosovo. As the major power

\footnotetext{
6 Brajshori M.J. 2019. A road map for the Kosovo-Serbia dialogue. Atlantic Council. URL: https://www.atlanticcouncil.org/ blogs/new-atlanticist/a-road-map-for-the-kosovo-serbia-dialogue/ (accessed 22.04.2020).

7 Angelovski I., Marzouk L., Graham-Harrison E. 2015. Tony Blair advising Serbian government 16 years after bombing of Belgrade. The Guardian. URL: https://www.theguardian.com/world/2015/feb/18/tony-blair-advising-serbian-government (accessed 16.04.2020).

8 Haradinaj was strongly opposing the land swap while being the Prime Minister.

9 Thaci and Rama on "abolishing the borders": Creating Albanian space without boundaries is necessary. URL: https:// kossev.info/thaci-and-rama-on-abolishing-the-borders-creating-albanian-space-without-boundaries-is-necessary (accessed 22.04.2020).
} 
which guarantees Resolution 1244 and continually insists that the dispute should be resolved only in accordance with it, Russia would have no further say in the matter. The fulfilment of these two goals of NATO in one stroke would lead to the third, integration of Serbia into its ranks, as there would not be a single remaining obstacle. Having in mind that Serbia has signed a number of agreements with NATO, such as SOFA (Status of forces agreement) and IPAP (Individual Partnership Action Plans), especially since 2012, during Vučićs terms as the Minister of Defence, Prime Minister and President (Ponomareva, Frolov 2019: 43-44), there are strong grounds to believe that Serbia and subsequently Bosnia-Herzegovina would join NATO, which would make all countries of the Balkans part of the alliance. Russians became aware of this, so they continued to insist on Resolution 1244, including at the highest political level. During 2019 both President Vladimir Putin ${ }^{10}$ and Prime Minister Dmitry Medvedev ${ }^{11}$ insisted that Kosovo dispute could only be resolved with respecting Resolution 1244 and Serbian sovereignty.

A connection between all the key actors of the 'NATO deal' is the fact that they have all supported Hilary Clinton's campaign in the 2016 US presidential election. This was unanimous among the Albanian leaders both in Kosovo ${ }^{12}$ and in Albania, ${ }^{13}$ where Clinton's popularity comes from her family background and because of her continued support for the Albanian national cause. Vučićs motives are more intriguing. Although he was the Minister of Information in Slobodan Miloševićs government in 1999, thus an active (and rather extreme) promoter of narrative in which Bill Clinton was regarded as the strongest symbol of the NATO aggression against the country, Vučić was the one sitting next to this former US President at an event organised by the Clinton Foundation during the peak of his wife's presidential campaign ${ }^{14}$. In light of this, it only made sense that Tony Blair who was Clinton's ally in bombing campaign of 1999 as British Prime Minister (Angelovski, Marzouk, Graham-Harrison 2015) and Jr. Soros ${ }^{15}$ are Vučićs advisors. This also explains why NATO, which is an integral part of Clinton's ideological frame, is supporting the Serbia-Kosovo 'border correction' plan.

The whole deal was strongly opposed in 2019 by Ramush Haradinaj, former warlord and then-Prime Minister of interim Kosovo institutions. He was among those

\footnotetext{
10 Провокации Косово могут привести к дестабилизации на Балканах, заявил Путин [Кosovo provocations could lead to destabilisation in the Balkans, Putin says (In Russ.)]. URL: https://ria.ru/20190117/1549515638.html (accessed 22.04.2020). ${ }_{11}$ Россия готова помочь Сербии в сохранении суверенитета, заявил Медведев [Russia is ready to help Serbia maintain sovereignty, Medvedev said (In Russ.)]. URL: https://ria.ru/20191019/1559975113.html (accessed 22.04.2020).

12 Thaci: Clinton likely to win, Albanians, vote for her. URL: https://www.b92.net/eng/news/politics. php?yyyy=2016\&mm=10\&dd=21\&nav_id=99477 (accessed 22.04.2020).

${ }^{13}$ Gerstein J. 2017. Albanian prime minister's date with Obama. Politico. URL: https://www.politico.eu/article/albanianprime-minister-edi-rama-date-with-barack-obama-guilty-fundraising/ (accessed 21.04.2020).

${ }_{14}$ Aleksandar Vucic, Bill Clinton. Tribina, New York. 2016 (video file). URL: https://www.youtube.com/watch?v=gj7-V1ryQ8U (accessed 22.04.2020).

${ }^{15}$ Vucic and Soros talk civil society and Kosovo. URL: https://www.b92.net/eng/news/politics. php?yyyy=2018\&mm=08\&dd=29\&nav_id=104955 (accessed 20.04.2020).
} 
who publicly exposed the plan, until then covered by the veil of secrecy ${ }^{16}$. Haradinaj even went so far as to accuse Rama and Thaçi of having a lucrative secret deal with Vučić that would bring the three of them profit of 10 billion euros, which provoked Rama to threaten Haradinaj with libel lawsuit ${ }^{17}$. Haradinaj said that " $[t]$ his was the hidden economic aim of the exchange of territories between Kosovo and Serbia. Thaçi, Vucic and Rama were accomplices in this scheme"18. He is also aware that if Thaçi's concept wins and he becomes the undisputed leader of the Kosovo Albanians, Haradinaj's political career might be over.

For Thaçi the stakes are even higher. If he does not become a great deal striker in the Balkans, recognised as someone who, together with Vučić and Mogherini, brought a lasting peace, he might face charges of war crimes in The Hague (at the Specialist Chambers for war crimes committed in Kosovo). Haradinaj's stubbornness against Thaçi's, Rama's and Vučić's plans suggests that he fears he could be the one whose power and freedom might be at stake if the deal is implemented. He actually resigned once the tribunal called him, ${ }^{19}$ with the resignation provoking the parliamentary election in 2020, which made Albin Kurti, young charismatic leader of the anticorruption and ultranationalist Self-Determination paerty, the key political figure among Kosovo Albanians.

Is Haradinaj speaking solely on his own behalf, or is he representing someone else's voice? More specifically, the question is if Haradinaj is at least to some degree a voice of a force that is opposed to the Mogherini-led (during her mandate) plans made by the EC and NATO?

While Germany is a very vocal opponent of redrawing Balkan borders ${ }^{20}$, the United Kingdom also seems to follow these lines, since it has officially voiced discontent over the issue $^{21}$, and the United States is hesitant to support the idea. Perhaps here lies the answer to Haradinaj's 'non-cooperative' attitude towards territory exchange. As for the official statements, there are two blocs regarding this topic in the political West: NATO, EC, France, Turkey and Austria (throughout Sebastian Kurtz's first term in office) supporting the Vučić-Thaçi-Rama-Mogherini deal, on the one hand, and Germany (UK and possibly the US) that are opposing it, on the other.

Haradinaj has resorted to populist rhetoric, saying he would not allow the land swap. He also said that Belgrade (Vučić) is lobbying for this agenda. Furthermore, he

\footnotetext{
${ }^{16}$ Kosovo's prime minister: We will not accept Serbia's violation of our sovereignty. Washington Post. URL: https://www. washingtonpost.com/news/global-opinions/wp/2018/11/28/kosovos-prime-minister-we-will-not-accept-serbias-violation-of-our-sovereignty/?utm_term=.938642dfc904 (accessed 22.04.2020).

${ }^{17}$ Erebara G. 2019. Albanian PM to Sue Kosovo's Haradinaj for Libel. Balkan Insight. URL: https://balkaninsight. com/2019/10/25/albania-prime-minister-plans-to-sue-kosovos-haradinaj-for-libel/ (accessed 22.04.2020).

${ }^{18} \mathrm{Ibid}$.

${ }^{19}$ Kosovo Leader Resigns After Being Called to War Crimes Court. New York Times. URL: https://www.nytimes. com/2019/07/19/world/europe/kosovo-leader-resigns-after-being-called-to-war-crimes-court.html (accessed 22.04.2020). ${ }^{20}$ Gray A. 2019. Angela Merkel: No Balkan border changes. Politico. URL: https://www.politico.eu/article/angela-merkelno-balkan-border-changes-kosovo-serbia-vucic-thaci/ (accessed 21.04.2020).

${ }^{21}$ London against border changes in Balkans. URL: http://ba.nlinfo.com/English/NEWS/a282068/London-against-borderchanges-in-Balkans.html (accessed 21.04.2020).
} 
has accused Serbia of trying to give Kosovo an obscene offer for the territorial swap. Even more precise than Haradinaj was the former Serbian Minister of Foreign Affairs Vuk Jeremić who claims that the deal between Vučić, Thaçi and Mogherini was struck in a series of secret meetings among which the most important one took place on the premises of the EU Delegation to the Holy See ${ }^{22}$.

Judging from the political tones coming from Berlin, it seems that Haradinaj's thoughts have been in line with the views of Angela Merkel. The German chancellor repeatedly sent the clear message that Europe does not want to redraw borders on its territory. So, if that is the case, then the political struggle in Kosovo is but a reflection of two rival concepts in the political West. One is oriented towards consolidating the territory of NATO at any cost and consolidating the EU and NATO members in the struggle against Russia. The other is concerned about possible outcomes of such a push and the likelihood of unforeseen consequences. By pulling the Balkans and Serbia for that matter into NATO, this part of the political West is again-just like in late- $19^{\text {th }}$ and early- $20^{\text {th }}$ century - "creating a powder cag for Europe" (Vishnyakov, Ponomareva 2018).

The side arguing and lobbying for a 'compromise' that would lead to territorial exchange was waging a scaremongering campaign. The essence of the campaign was to represent the so-called frozen conflict as the worst possible scenario for Kosovo. Frozen conflict became a media bogeyman repeated over and over in the media and more importantly by various lobbyists involved. Again, Timothy Less was the first to test out the idea of redrawing the Balkan borders based on a Huntingtonian (Huntington 1996), essentially racist, presumption that different ethnic and religious communities cannot live together. It was Less who spread the fear of the frozen conflict which, if not solved, would bring about catastrophic consequences not only for the region, but for the political West as a whole.

"On the contrary, the region is one of the least stable in Europe, where divided, multi-ethnic states subsist in a state of frozen conflict, requiring the presence of thousands of international peacekeepers on the ground to prevent a relapse into violence. [...] With the political crisis in the EU deepening, the Europeans have lost their focus, their authority and their main policy lever in the region, namely the promise of EU integration. Meanwhile, the Americans have more important concerns than the Balkans on their plate. In the space vacated by the West, Russia and Turkey are asserting their presence and pushing their own self-interested agendas" (Less 2016).

As stated in his 2016 paper, Less is especially concerned about the possible Russian (and Chinese) interference in the Balkans through Serbia, but also about the interference of other third parties such as Turkey. That could all lead to more complications, Less argues, if the West does not respond accordingly.

\footnotetext{
22 Јеремиђ изнео тешку оптужбу. URL: http://www.pravda.rs/2018/12/15/jeremic-izneo-tesku-optuzbu-tzv-vojska-kosova-dogovorena-na-tajnom-sastanku-u-vatikanu/ (accessed 21.04.2020).
} 
"To complicate matters, Russia is using its influence to frustrate the process of integration, encouraging unhappy minorities such as the Bosnian Serbs to escalate their demands for separatism and threatening the pro-integration government in Montenegro. Turkey is nurturing the support of disaffected Muslims such as Bosniaks and Macedonian Albanians. And China is enthusiastically providing governments across the region with no-strings funding for investment in infrastructure, undermining the West's attempts to promote conditions-based internal reform" (Less 2016).

Less defends his argument for a likelihood of this new wave of self-determination based on ethnic grounds, referring to Woodrow Wilson's ideas voiced at the Versailles peace conference after World War One: "In pursuing this plan, the United States would not be breaking new ground but simply reviving the Wilsonian vision of a Europe comprising self-governing nations" (Less 2016).

Besides Less, a few different papers, or strategic assessments, were written in a similar tone about the situation in the Balkans, most notably "Balkans Forward: A New US Strategy for the Region” by the Atlantic Council (Marusic, Bedenbaugh, Wilson 2017) and "Time for action in the Western Balkans - Policy presentations for American diplomacy" by the National Committee on American Foreign Policy \& East West Institute in May 2018 (Graham, Levitsky, Munter \& Wisner 2018). A key recommendation of the latter is:

"To stop the slow slide to a frozen conflict, the United States should encourage the E.U. to revitalise the Kosovo-Serbia dialogue. The dialogue must lead to Serbia's recognition of Kosovo as an independent state. The U.S. should be prepared to accept measures that the parties agree to as part of their normalization of relations" (Graham, Levitsky, Munter \& Wisner 2018: 4).

Nevertheless, it is highly questionable whether these recommendations will be implemented, having in mind the strong opposition from London, Berlin and perhaps some circles in Washington. On the other hand, Moscow and Beijing are also opposed to solutions that might lead to NATO-isation of the Balkans, for their own reasons.

\section{All are welcome in NATO - whether they like it or not}

Judging by the policies they implement, it would not be an overstatement to say that a group of presidents and prime ministers dominates the whole of the Balkans, all of whom are a part of, let us call it, NATO's deep state.

Vučić got into a serious conflict with the Serbian Orthodox Church over Kosovo the same way Alexis Tsipras has with the Greek Orthodox Church, over the 2018 EU-brokered Prespa Agreement with Skopje ${ }^{23}$. Macedonian Prime Minister Zaev was, needless to say, also under great internal pressure because of the deal that changed the name of his country, as if the NATO enlargement was more important/sacred than the

\footnotetext{
${ }^{23}$ Prespa Agreement 2018. URL: https://vlada.mk/sites/default/files/dokumenti/spogodba-en.pdf (accessed 21.04.2020).
} 
interest of their own people and states. The enlargement of NATO was actually at the heart of the deal between Greece and Macedonia (now North Macedonia). In truth, no one would have been bothered in Brussels about the name of the Former Yugoslav Republic of Macedonia if the name issue has not been the last obstacle in the way of the country to join NATO. Once NATO showed a true initiative to integrate Macedonia, the name issue came up as a problem, since every NATO member had to ratify the accession agreement in its national parliament. It was clear Greece would never agree with that unless their northern neighbour changes its name because the northern region of the Hellenic state is also called Macedonia, besides the issue of Macedonian historiography appropriating the ancient Macedonian history from the Greeks.

The Macedonian referendum on the agreement failed due to low turnout, a result of the boycott by those opposed to changing the country's name. However, the behaviour of Brussels in the aftermath of that failure has shown that there are hardly any principles that they are not willing to break in order to pursue their geopolitical interest. The referendum question was: "Are you in favour of European Union and NATO membership by accepting the agreement between the Republic of Macedonia and the Republic of Greece?" The referendum failed. Or did it? According to the Macedonian constitution the referendum results are binding and the referendum is successful if the turnout is over $50 \%$. However, the turnout was $36.91 \%{ }^{24}$ and the referendum legally failed. Nevertheless, the political West was unanimous in its assessment that the referendum was a celebration of democracy showing the will of the people, so the Prespa agreement eventually passed, Macedonia changed its name and the road to NATO membership was clear. Northern Macedonia eventually became a member of NATO on 27 March 2020, during the COVID-19 pandemic.

In Montenegro, there was no NATO membership referendum at all, which yet again was not a problem for Western democracies. Although for years the Montenegrin authorities have been promising a referendum on joining NATO, it never took place. Instead, the accession was voted by the parliament. However, there was an episode in this story that can almost be called humorous. The then-President of Montenegro Filip Vujanović has been promising the citizens for years that they would be asked if they agreed to their country joining NATO. That was too great of a risk both for NATO and for the Democratic Party of Socialists, Montenegro's unchangeable ruling party (the rebranded branch of the Communist Party which has been in power since the break-up of Yugoslavia), which is why it did not happen. However, when it became clear that no referendum would take place, Vujanović remained unabashed saying, on camera, he did not trick anyone, but had merely "changed his mind"25.

\footnotetext{
${ }^{24}$ Over $90 \%$ of Macedonian Referendum Voters Chose to Rename Country. Sputnik International. URL: https://sputniknews.com/europe/201810011068496629-macedonia-referendum-vote-results/ (accessed 31.03.2020).

${ }^{25}$ Filip Vujanović se predomislio u vezi referenduma [Filip Vujanovic changed his mind about the referendum (In Serb.)], 2017 (video file). URL: https://www.youtube.com/watch?v=eHqRC09x86A (accessed 30.03.2020).
} 
These episodes in Macedonia and Montenegro, had not they been part of calculated policies with serious consequences, would make for a good sketch in the Monty Python's Flying Circus, a famous British comedy programme. The geopolitical interest of pro-Atlantic forces is disguised by so-called democratic principles, but becomes fairly clear from the above-mentioned Atlantic Council's strategy for the Balkans:

"Montenegro's accession to NATO presents one opportunity to help an emerging partner make good on its commitment to genuine democratic reforms. The breakthrough of Europe-focused reformers in Macedonia presents another. The United States should pursue a more intentional effort to prepare Athens and Skopje to become future allies, and join the EU to push the Belgrade-Pristina talks into the endgame" (Marusic, Bedenbaugh, Wilson 2017: 3).

Not surprisingly, Montenegrin case was compared to Macedonian. In both cases, NATO utilised obscure methods to find 'legal' ways to 'swallow' both tiny states. To seal the accession to NATO, Montenegrin authorities went so far as to fabricate a coup d'état affair (Bajrović, Garčević, Kraemer 2018). On the day of the parliamentary election on 16 October 2016, there was a fair possibility that the anti-NATO opposition could defeat the Democratic Party of Socialists that had ruled the country since $1991^{26}$. Towards the end of the election day, the regime started a scaremongering campaign that included media attacks, a series of arrests and later on, in the months to follow, a very dubious legal process. In fact, this strategy used by the Montenegrin ruling party was a textbook example of voter suppression.

The regime claimed that the Russian agents were planning a plot to overthrow the authorities in Montenegro. Amid the media noise and fears spread through the society, it was easy for the regime to undermine political freedoms, push the country into the North Atlantic alliance without the promised referendum, organise a witch hunt against everybody who was opposed to NATO integration, accusing them of being Russian agents, and so forth. All these violations were justified by the need to defend the country from the concocted Russian threat.

Needless to say, NATO officials and pro-NATO structures were fully aware of these actions of the Montenegrin regime.

"Montenegro, the smallest country in the region, demonstrated last year its firm commitment to join trans-Atlantic structures. Montenegrin authorities thwarted a Russian-backed coup to topple the NATO-friendly government and became the 29th NATO member. Its accession served as a signal to other states in the region that membership in the trans-Atlantic community was still an option" (Graham, Levitsky, Munter. \& Wisner 2018: 15).

\footnotetext{
${ }^{26}$ Democratic Party of Socialists is the rebranded Montenegrin branch of the Yugoslav Communist Party. Milo Đukanović is practically in power since 1989 after a group of young Serb nationalists within the Communist Party of Montenegro won the power struggle for party leadership. The series of events that brought this group to power is known as AntiBureaucratic Revolution.
} 
On the wings of this rhetoric of officials in the political West, it was easy for Montenegrin regime to silence the opposition, in the manner of US-backed Latin American dictatorships.

Croatia's former president Kolinda Grabar Kitarović was not only a pro-NATO president; she actually left her high-ranking position of Assistant Secretary General for Public Diplomacy in the Alliance to run for presidency of Croatia in 2015. It is therefore not surprising that she was one of the most ardent NATO enthusiasts in the Balkans and Eastern Europe in general. Grabar Kitarović was very keen on promoting the so-called Three Seas Initiative which aims to: "contribute to the strengthening of transatlantic ties. The US economic presence in the region provides a catalyst for an enhanced transatlantic partnership" 27.

In essence, the Three Seas Initiative seeks to block Russia from the zone stretching from Baltic to the Black sea and the Mediterranean, an idea that is not new as originated in the cause of the 1853-1856 Crimean war. The initiative bears even more resemblance with the ideas of the Polish leader Marshal Józef Piłsudski, particularly his views on creating the Intermarium federation which would block Russia from the rest of Europe (Chodakiewicz 2012).

"From the Russian perspective, contemporary NATO-EU enlargements into the Central and Eastern European 'shatter belt' can furthermore be compared and contrasted with Polish efforts to forge a European con- federation or 'Intermarium' after the breakup of the Tsarist Russian and Austro-Hungarian Empires, but before Soviets re-absorbed parts of Belarus and Ukraine. In the Russian view, NATO, backed by American hegemony, has been attempting to fulfill the early interwar period project of Polish President Józef Pilsudski for a potential Eastern European federation or 'Intermarium'. [...] Warsaw not only saw this 'Intermarium' project as a means to build an Eastern European confederation between Weimar Germany and the Soviet Union in the interwar period, but the goal was also to break up the Soviet Union under the complementary project, 'Prometheism.' [...] In effect, since the second wave of NATO expansion in 2004 and particularly with respect to the promises of bringing Ukraine into NATO at some point in the future, NATO has appeared to be backing Pilsudski's old project in which Poland was to lead a European federation that was to include Finland, Estonia, Latvia, Lithuania, Belarus, Czechoslovakia, Hungary, Romania, Ukraine and Yugoslavia. Of the latter states, only Belarus, Ukraine and Finland have not joined NATO" (Gardner 2019: 249-250).

Creating hubs for liquified natural gas (LNG) that, although significantly more expensive, directly competes with the Russian gas that Europeans import, is a specific infrastructural step to block Russia. One hub is to be constructed in Poland, and another is planned on being built in Croatia. That is a very clear example of Croatian exPresident's enthusiasm for NATO running against the will of Croatians. Specifically,

\footnotetext{
${ }^{27}$ Three Seas Initiative Summit 2018. URL: http://three-seas.eu/about/ (accessed 17.04.2020).
} 
the population of Omišalj, a town on the Island of Krk where the LNG terminal is supposed to be constructed, are protesting against the plan, which would destroy their income from tourism and heavily impact the environment. Both town and regional authorities joined them in this opposition. The fears are supported by the fact that the real estate prices in the town started to drop rapidly after the news about the construction came out ${ }^{28}$. The terminal is nonetheless being built because the decision has been made on the top level.

Apart from Serbia, Bosnia-Herzegovina is the only country in the Balkans that is not a member of NATO, nor is it on the clear path to North Atlantic integration, Nonetheless, NATO is very interested in integrating it. At the moment, Republika Srpska ${ }^{29}$ is bound to maintain military neutrality by the resolution ratified by its parliament ${ }^{30}$. Moreover, NATO is highly unpopular among Serbs in Bosnia because it was directly involved in the civil war (1992-1995) on the side of the Serb adversaries. Before bombing Serbia and Montenegro in 1999, Serbs felt oppressed by NATO in Bosnia-Herzegovina in 1994 and 1995. These are the reasons why Republika Srpska has been blocking (or has been strongly resisting) the Membership Action Plan (MAP) so far. Former President of Republika Srpska and now the member of the Presidency of Bosnia-Herzegovina, Milorad Dodik, opposed MAP for years. However, he signed the Programme of Reforms of Bosnia-Herzegovina, which might potentially move the country closer to NATO. Although Dodik claimed that this does not mean that he has breached the military neutrality of Bosnia-Herzegovina, the opposition was not convinced.

Serbia's policy is also ambiguous. Although it is officially militarily neutral ${ }^{31}$, in accordance with a 2007 parliamentary resolution ${ }^{32}$, and although Serbia is very keen to show it is conducting joint military exercises with Russia and China, the majority of its international military cooperation is connected to NATO. Serbia is a member of Part-

\footnotetext{
${ }^{28}$ Romac D. 2018. Ni energetika, ni ekologija, već politika [No energy, nor ecology, only politics (In Serb.)]. Deutsche Welle. URL: https://www.dw.com/sr/ni-energetika-ni-ekologija-ve\%C4\%87-politika/a-42841208-0 (accessed 22.04.2020).

${ }^{29}$ Republika Srpska was established founded on 9 January 1992, during breakup of Yugoslavia. It became one of the two constituent parts of Bosnia-Herzegovina when the Dayton Peace Agreement put an end to the civil war in 1995.

${ }^{30} \mathrm{Ha}$ 22. редовној сједници усвојена Резолуција о заштити уставног поретка и проглашењу војне неутралности [ТТе $22^{\text {nd }}$ Regular Session adopted a Resolution on the Protection of the Constitutional Order and the Proclamation of Military Neutrality (In Serb.)]. URL: https://www.narodnaskupstinars.net/?q=ci/вијести/на-22-редовној-сједници-усвојенарезолуција-о-заштити-уставног-поретка-и-проглашењу-војне-неутралности (accessed 30.03.2020).

${ }^{31}$ At present, Serbia is trying to balance its political-economic relations with NATO, the EU and Russia. If a conflict erupts, NATO is capable of "encircling" Serbia which has not joined NATO and has had historic ties with Russia. This way, Serbia could once again become involved in a major war. Yet, unlike the situation before World War I, the "Greater Middle East" (including Afghanistan, Syria, and Yemen) rather than the Balkans will most likely become the main stage for such a conflict to sparkle (Gardner 2019).

32 Резолуција Народне скупштине о заштити суверенитета, територијалног интегритета и уставног поретка Републике Србије [National Assembly resolution on the protection of the sovereignty, territorial integrity and constitutional order of the Republic of Serbia (In Serb.)]. URL: https://www.srbija.gov.rs/kosovo-metohija/index.php?id=80729 (accessed 10.04.2020).

${ }^{33}$ Serbia adopts new IPAP with NATO. URL: http://rs.n1info.com/English/NEWS/a542015/Serbia-adopts-new-IPAP-withNATO.html (accessed 18.04. 2020).
} 
nership for Peace; it has signed SOFA and has adopted the second IPAP ${ }^{33}$ agreement. At the same time, the Russian staff of the Serbian-Russian Humanitarian Centre in Niš do not have the diplomatic immunity status although Russia has repeatedly reminded Serbia of the issue.

As an even more stereotypical development and in a fashion similar to the Montenegrin scenario (the above described coup d'état affair), Vučić in essence accused Russia's military security service GRU of recruiting a retired Serbian military intelligence officer $^{34}$. Just in November that year, Serbia quietly made another step closer to NATO by adopting a new IPAP agreement ${ }^{35}$. This happened at the peak of a true scandal, when a private company connected with the father of Serbia's interior minister and one of Vučićs closest associates Nebojša Stefanović was buying ammunition from a state-owned factory under very favourable conditions. Not only that this was a conflict of interest, but this ammunition ended up in the hands of Yemen islamists ${ }^{36}$ and also in the Ukraine $e^{37}$. By drawing media attention to the fabricated spy scandal, Vučić may have thought that he could divert the attention from a true arms smuggling scandal and get the kind of support from NATO that Đukanović enjoyed earlier. Some support $^{38}$ indeed came, but Vučić, although mildly accusing Russia, did not communicate the same message as Montenegrin regime in 2016. It seems that Vučić, burdened by numerous political and criminal scandals, does not have the muscle to pull the Montenegrin scenario all the way through.

Even if Serbia does not formally join NATO, it is clear that the globalist part of the political West is trying to drag Serbia into its military bloc in one way or another through a network of different political, economic and security associations, through Partnership for Peace, IPAP and several regional cooperation's with its NATO neighbours, such as the HELBROC Balkan battle group (Greece, Bulgaria, Romania, Cyprus, Ukraine and Serbia), the 'Quadrilateral' (previously known as the Craiova group consisting of Serbia, Romania, Bulgaria and Greece) or what Vučić likes to call 'Little Schengen ${ }^{39}$ (with Albania and Northern Macedonia). French President Emanuel Macron has a more subtle approach and does not insist that Serbia should join NATO,

\footnotetext{
${ }^{34}$ Вучић: Руског амбасадора само сам питао - зашто [Vucic: I was just asking the Russian ambassador why (In Serb.)]. URL: http://www.rts.rs/page/stories/ci/story/1/politika/3745748/vucic-ruskog-ambasadora-samo-sam-pitao-zasto.html (accessed 21.04. 2020).

35 Serbia adopts new IPAP with NATO. European Western Balkans 2019. URL: https://europeanwesternbalkans. com/2019/11/08/serbia-adopts-new-ipap-with-nato/ (accessed 21.04.2020).

${ }^{36}$ Gaytandzhieva D. 2019. Islamic State weapons in Yemen traced back to US Government: Serbia files (part 1). URL: http:// armswatch.com/islamic-state-weapons-in-yemen-traced-back-to-us-government-serbia-files-part-1/ (accessed 29.03. 2020).

${ }^{37}$ Gaytandzhieva D. 2019. Serbian arms trafficked to Ukraine: evidence of contraband mortars used against Donbass. URL: http://armswatch.com/serbian-arms-trafficked-to-ukraine-evidence-of-contraband-mortars-used-against-donbass/ (accessed 27.03. 2020).

${ }^{38}$ McLaughlin D. 2019. US scolds 'destabilising' Russia and urges Serbia to act on spy scandal. The Irish Times. URL: https://www.irishtimes.com/news/world/europe/us-scolds-destabilising-russia-and-urges-serbia-to-act-on-spy-scandal-1.409362 (accessed 28.03.2020).

${ }^{39}$ Western Balkan Leaders Discuss 'Little Schengen' Project. Radio Free Europe. URL: https://www.rferl.org/a/balkan-leaders-little-schengen-rama-vucic-zaev/30262863.html (accessed 23.04. 2020).
} 
perhaps because he himself does not seem to believe in NATO's future anymore and has been speculating about establishing Europe's own military bloc. Nevertheless, both soft or hard wings of the West are equally uneasy about any potential military presence of Russia, and perhaps China, in Serbia. Macron also expressed concerns about the factor of political Islam in the Balkans ${ }^{40}$ and is anxious about Turkey, the unofficial patron of the Balkan Muslims, which he views as a troublemaker. He even implied that Turkey helped ISIS by unilaterally attacking the Kurds in Syria without consulting its allies $^{41}$.

The only vision NATO seems to have for the Balkans is full integration and for the Serbs, absolute capitulation as the only compromise they could and should hope for. NATO-orchestrated changes in Kosovo, Republika Srpska, Montenegro, Macedonia, and relations with Russia are the most glaring examples of such a calculated policy. The new cold war with Russia is what is driving the rapid NATO-isation of the Balkans, so is the general insecurity and dissonant tones coming from different centres of the political West. Lord Hastings Lionel Ismay, NATO's first Secretary General, once famously said that the role of NATO is to "keep the Soviet Union out, the Americans in, and the Germans down"42. From early 1990's, the goal of NATO in the Balkans has been to keep the Russians out, NATO in, and the Serbs down.

This naturally means getting Russia out of the Balkans by all means, in accordance with Zbigniew Brzezinski’s strategy of encircling Russia (Brzezinski 2016). Again, Serbia as the heart of the Balkan watermelon, to put it metaphorically, is the main target, as it was back in 1999. A document published by the Atlantic Council is very explicit about this goal:

"Belgrade can and should be a close partner and ally in the region, but it can only become one if it begins to meaningfully distance itself from Russia. This is not a trivial pivot for Serbian leadership, but neither should it be something on which the United States or the EU should compromise" (Marusic, Bedenbaugh, Wilson 2017: 3).

The fear of the alternative scenario is also explicitly stated: "As the United States and Europe focus on internal concerns, Russia and other countries are reshaping the geopolitical landscape across the region" (Marusic, Bedenbaugh, Wilson 2017: 1).

\section{What about Russia?}

A good question to be asked is where is Russia in all this. After all, it is the 'Russian meddling' that worries NATO, not only in the Balkans, but in other regions too.

\footnotetext{
40 "If you're concerned about this region, the first question is neither Macedonia, nor Albania, it's Bosnia-Herzegovina. The time-bomb that's ticking right next to Croatia, and which faces the problem of returning jihadists, is Bosnia-Herzegovina." (Emmanuel Macron in his own words. The French president's interview with The Economist. 2019. The Economist. URL: https://www.economist.com/europe/2019/11/07/emmanuel-macron-in-his-own-words-english (accessed 21.04.2020)

${ }^{41}$ Macron Says:" Russia, China Not NATO Allies Common Enemies - Terrorism Is". Radio Free Europe. URL: https://www.rferl. org/a/macron-says-russia-china-not-nato-allies-common-enemies---terrorism-is/30297520.html (accessed 20.04. 2020).

42 Lord Ismay. NATO website. URL: https://www.nato.int/cps/en/natohq/declassified_137930.htm (accessed 22.04.2020).
} 
Russia did next to nothing when Bulgaria, Romania, Albania and Croatia, all in the Balkans, similarly to other countries further to the north, joined NATO, contrary to the 'gentlemen's agreement' between the Soviet Union leader Mikhail Gorbachev and US Secretary of State James Baker, who on 9 January 1990 assured that NATO would not spread "one inch eastward" (Majumdar 2017). However, after the Georgian war in 2008, if not earlier, after Putin's Munich speech in 2007, Russia certainly has increasingly showed its discontent with the aggressive NATO enlargement eastwards, closer and closer to its borders.

In cases of Montenegro and Macedonia, not only was Russia supine, but it was defeated in a fight it was not even trying to fight, or it did so in a very awkward manner, as if caught off-guard. Montenegrin government accused Russia of staging a failed coup d'état, and there were numerous accusations of it meddling in Macedonia too. However, if that was the case, those may have been the poorest instances of meddling since any positive outcome for Russia was absent, with the global media blaming it nonetheless. While Russia stood accused of aggressive interference, in fact it passively observed NATO integrating countries of the region one by one, in most cases against the will of their citizens. That was an expensive lesson to learn, but Russia does not seem to be willing to repeat the same scenario in Serbia and BosniaHerzegovina. Nevertheless, the realisation was a result of an evolutionary process Moscow underwent.

In the very beginning, it seemed that dissonant tones could be heard from Russia. One consistent and firm message that the Ministry of Foreign Affairs kept sending was that borders should not be changed as, according to the UN Security Council resolution 1244, Kosovo is an integral part of Serbia. However, another message communicated by both various Kremlin officials and private voices, conveyed a softer, more flexible position that the deal negotiated by Belgrade and Pristina might be acceptable. Such a position may have been taken on the basis of a rather naïve assumption that Serbia's officials were guided by their best intentions, which is to protect Serbia's national interests. However, the non-transparent deals between Vučić, Thaçi and Mogherini were, as the public later found out, undoubtedly made to violate Serbia's sovereignty. Vučić exploited the traditional friendship Serbian-Russian and the genuine trust he enjoyed among the Russian officials, to push forward the border change agenda, or, from the perspective of the Serbian constitution, giving away most of Kosovo and Metohija to a country that Serbia supposedly does not recognise.

One of the statements that were heavily exploited by Vučićs propaganda apparatus was that of Aleksey Pushkov, Chair of the Information Policy \& Communications Committee of the Federation Council. Serbian regime's interpretations were along the lines that Moscow has nothing against the Vučič-Thaçi deal. In an interview given to Sputnik Serbia, Pushkov said:

"Yes, we protect the interests of Serbia because Serbs are our allies, and Serbia says that Kosovo cannot be the member of the United Nations. If Serbia says tomorrow that Kosovo should be the member of UN, then Russia may take a different decision. Our 
position on the Kosovo issue largely depends on the position of Belgrade. If Belgrade changes its mind, we might also reconsider our approach"43.

Statements like that, although not resolutely advocating the Vučić-Thaçi deal, were often interpreted by the media under Vučićs's control in Serbia as Russia's green light for the territory swap.

Once the Russian leadership realised that had Vučić tried to trick them by sharing with them the burden of responsibility and fault in the eyes of the Serbian public for his plan, the rhetoric of the official Moscow became very unilateral and unambiguous. The change was even noticeable in Russia's mainstream media ${ }^{44}$.

Moreover, the beating of the Russian diplomat working at the UN mission in Kosovo - UNMIK by the Kosovo Albanian security forces was seen as a direct provocation against Russia, which also pushed it to adopt a firmer position on supporting Serbia's territorial integrity and sovereignty over Kosovo. Subtle change in attitude became crystal clear in President Putin's statement during his visit to Belgrade on 17 January 2019:

"Russian President Vladimir Putin said in Belgrade on Jan. 17 that Russia supported a mutually acceptable solution for Kosovo and Metohija based on UN Security Council Resolution 1244. Russia, like Serbia, is interested in the Balkans staying stable and safe. Russia's stance on Kosovo is known, we support reaching an acceptable solution based on Resolution 1244 [...] Kosovo army is directly violating Resolution 1244 [...] It is necessary to honour international law more and then a just solution will be possible, the Russian president said, adding that Russia would work with its partners to ensure that a just solution was reache" ${ }^{\prime 4}$.

Prime Minister Medvedev conveyed a similar message during his visit to Belgrade in October same year. In other words, Putin said that the deal that would lead to changes in Serbia's borders is out of the question. Moscow realised that if it agreed with changing resolution 1244, it would be pushed out of the Balkans for good and there would be no legal grounds that could prevent NATO from integrating Serbia and Bosnia-Herzegovina. It is certain that after Vučićss spy scandal stunt, Russian leadership is even more convinced in the validity of supporting the existing UN resolution.

\footnotetext{
43 Пушков: Србија је против уласка Косова у УН, али ако се то промени... [Pushkov: Serbia is against Kosovo's entry into the UN, but if that changes (In Serb.)]. Cпутњик Србија. URL: https://rs.sputniknews.com/intervju/201810231117590724kosovo-puskov-un-rusija-/ (accessed 17.04.2020).

${ }^{44}$ In the popular political TV show International Review on state TV channel Russia 24, member of the state Duma and famous journalist Yevgeny Primakov (also the grandson of Yevgeny Primakov, Russia's former Minister of Foreign Affairs and Prime Minister during Boris Yeltsin and NATO bombardment of Yugoslavia in 1999) in a discussion about Serbia with his guest Nikita Bondarev said: "At a certain moment the Serbian patriotic opposition, that also exists there [in Serbia], could say that Russia is betraying Serbia on Kosovo issue, to NATO and so on, by supporting everything that the regime in Belgrade is doing." Международное обозрение [International Review (In Russ.)]. 2019. 30 November. (video file). URL: https://www.youtube.com/watch?v=UDQtMu1QPqA (accessed 10.04.2020).

${ }^{45}$ Vucic: Without Russia no Solution for Kosovo and Metohija is Possible. URL: http://www.mfa.gov.rs/en/press-service/ daily-news (accessed 29.03. 2020).
} 
One thing is evident; Russia does not want to be isolated from Europe and free access to the Mediterranean and Baltic seas by some kind of a new Intermarium called The Three Seas Initiative, or in any other form for that matter. That is why it is crucial for Russia to keep the Balkans in their current status, not fully integrated into NATO and with at least some of the countries of the region remaining militarily neutral. Swift integration of Montenegro and North Macedonia into the alliance were two harsh blows for Russia. To add a pinch of salt, these blows were followed by a global anti-Russian campaign of the pro-NATO world media. Russia's new red line was drawn behind Serbia's (and Bosnia's) military neutrality. To demonstrate its sternness, in October 2019 Russian military tested their cutting-edge anti-aircraft systems S-400 and Pantsir-S1 during a joint military exercise with the Serbian military ${ }^{46}$. That was a strong message on Moscow's part, unquestionably well-understood by NATO.

\section{Why the hurry? \\ From overstretch to potential dissolution of NATO}

It would be useful to identify some of the key reasons for the rush with which NATO has been trying to integrate all Balkan countries:

1. The post-Cold War ideological consensus in the West is challenged by the growth of non-systemic political movements. Until Trump is able to achieve full control over the State Department, ${ }^{47}$ the Balkans should be integrated in NATO. The political centre is losing its importance, and there only seems to be space for extreme political wings, both left and right. In a way, we are living in the The Age of the Intolerant (Mitrović 2004). "The end of history" (Fukuyama 1992) of the West seems to be getting closer: Brexit has polarised Great Britain to the extent unseen in the country in decades, if not centuries, with similar processes happening in virtually all Western societies.

2. The new Cold War with Russia. In the eyes of NATO, Serbs should be fully integrated and thus eliminated as a geopolitical factor and a potential 'Russian agent' in the Balkans. The Balkans should not contain a security gap in the front against Russia.

3. Since the European elections in May 2019 have changed the balance of power, Mogherini and the EU Commission wanted to leave a visible legacy and find a final political solution for Kosovo, i.e. to persuade Serbia to recognise it one way or the other. The EU's soft power has been in sharp decline.

4. China's presence is increasing. The Chinese bought Piraeus port, the largest sea terminal in the peninsula; they plan to construct a high-speed railway from Greece to

\footnotetext{
${ }^{46}$ Russia sends S-400 missile defense systems to Serbia for military drill. URL: https://www.reuters.com/article/us-russiaserbia-missiles/russia-sends-s-400-missile-defense-systems-to-serbia-for-military-drill-idUSKBN1X30VE (accessed 27.03. 2020).

${ }^{47}$ Trump recently referred to the US State Department as the 'Deep State Department' in front of State Secretary Mike Pompeo, at the same time publicly disciplining the latter and indirectly admitting that he (Trump) does not fully control the policies of the State Department. https://www.youtube.com/watch?v=c8xVXrp8cRE (accessed 27.03. 2020).
} 
Budapest and potentially Warsaw, passing through Northern Macedonia and Serbia. In Serbia, besides the involvement in many infrastructural projects, they bought both the largest complex of mines in Bor and the steel mill in Smederevo that used to belong to US Steel.

5. With the acknowledgment that Russia, China, Turkey, Iran and other powers are entering the Balkans, the political West has essentially recognised the onset of the age of multipolarity, with it no longer being the only game in town for the Balkan peoples. This became very evident during the COVID-19 outbreak and the PR battle surrounding the delivery of foreign aid from various powers for the countries of the region. That is precisely why the West seeks to bind the region, in the sphere of defence above all. Therefore, NATO integration is almost immanent while the EU integrations remain a promise not likely to ever be delivered.

By the time this article is published, more events may unfold, perhaps impacting the dynamics of the region even further.

It is the fear of NATO's potential dissolution, formal or informal, that has given rise to the organisation's hectic drive for enlargement, not only in the Balkans, but perhaps also in the Ukraine and South Caucasus. Although it is very common to equate US and NATO, we do not believe this is necessarily still the case. On the contrary, interests of the US and those of NATO, as an autonomous bureaucratic organism, are increasingly diverging. Things may seem even more confusing because different parts of the US political apparatus are sending conflicting messages on same issues, with some parts of government being more or less pro-NATO, such as the Department of State. However, the emerging conflict of interest between the US and NATO is growingly visible, of which the Balkans are a glaring example.

That is especially true as far as President Donald Trump's administration is concerned. Trump is undermining the Clintonian legacy at every opportunity, whether it is in Iran, Korea, Syria or the Balkans ${ }^{48}$. Appointing US Ambassador to Germany Richard Grenell as the President's personal emissary for the Kosovo issue might have been done only to serve the same purpose. The ideological war in the West in general is emanated from the clash between Trump's White House on the one hand and the deep state's Department of State on the other. Appointing Ambassador Grenell while the State Department already had its own envoy makes little sense unless one takes into account the conflict between Trump's vision and that of the State Department.

The marginalisation of Matthew Palmer's role in Belgrade-Pristina negotiations was a political consequence of Grenell's appointment. Palmer was a proponent of the

\footnotetext{
${ }^{48}$ Trump appears to be trying to implement a policy similar to Richard Nixon's, at the time when Henry Kissinger was the US Secretary of State. What is now known as 'Nixon's China' was a series of policies that originated from a strategic decision made by the White House to open the United States to China in order to contain the USSR. This was described in detail in chapter 28 (Foreign Policy as Geopolitics: Nixon's Triangular Diplomacy) of Kissinger's famous book Diplomacy (Kissinger 1994). Today, Trump is, in our opinion, attempting to partner with Russia to contain China; however, many still oppose the plan, especially the bureaucrats who remained in the Department of State since Clinton and Obama administrations.
} 
territory exchange scenario, which seems to be much less plausible after Grenell's first Balkan tour. Palmer's weakening position became obvious after his visit to Pristina in November 2019. He met Thaçi, but the politician that had just won the majority of MPs in the October parliamentary election and the Prime Minister with a very short (50 days) term Albin Kurti did not have time to meet with him, which was quite a humiliation for the State Department's envoy. Needless to say, Kurti met Grenell just a few weeks earlier.

In effect, the negotiation process led by NATO, US State Department, EU Commission and a number of other lobbyists came to a halt and may never resume in the same format or with the same probable outcome. Not only because Russia and China are clearly against violating Resolution 1244, but also because Trump's administration is far from being keen on the idea of territorial exchange or any kind of an instant solution of Kosovo dispute. In essence, Trump administration is not looking favourably at the Vučić-Thaçi-Rama-Mogherini deal. Bodo Weber, Senior Associate at the Berlinbased think-tank Democratisation Policy Council, shares this conclusion.

"The very fact that two special envoys have been appointed in parallel, in an uncoordinated way, Matthew Palmer, not as a Western Balkans representative, not from the Trump administration but only from the State Department, and Richard Grenell from the Trump's White House, in my opinion is a sign that the attention of the US Administration lessens compared to the previous years. This is more like a sign that they no longer have a new initiative" 49 .

Furthermore, Weber was extremely critical of the role that Mogherini played, accusing her of privatising the negotiations:

"European policy was completely privatized by Federica Mogherini and her team of four to five people. This is unique in the history of the common foreign and security policy of the EU, which has not got a long tradition, that the negotiation process was fully privatized by the top High Representative in charge of that policy" 50 .

In our opinion, the reason for such a policy towards the Balkans is the fact that Trump has never really abandoned his pre-electoral opinion that NATO is obsolete, and he has repeated the idea that the US might pull out of NATO at some point ${ }^{51}$. Trump's usual complaint (possibly merely an excuse for his anti-NATO stance) is that other NATO members are not paying enough for the common defence. It is very symbolic that it was Emanuel Macron, someone whose ideological stance differs greatly from Trump's, who paraphrased the American President's statement. Macron exclaimed, in his interview for The Economist.

\footnotetext{
${ }^{49}$ It seems to me that the US has no new initiative for the Balkans at all. URL: https://www.b92.net/eng/news/politics. php?yyyy=2019\&mm=11\&dd=25\&nav_id=107556 (accessed 25.03.2020).

50 lbid.

${ }^{51}$ Barnes J., Cooper H. 2019. Trump Discussed Pulling U.S. From NATO, Aides Say Amid New Concerns Over Russia. New York Times. 14 January. URL: https://www.nytimes.com/2019/01/14/us/politics/nato-president-trump.html (accessed 17.04. 2020).
} 
"What we are currently experiencing is the brain death of NATO [...] You have no coordination whatsoever of strategic decision-making between the United States and its NATO allies. None"52.

Macron also questioned the validity and binding power of NATO's Article 5, according to which an attack on one member state is considered as an attack against the whole alliance, which leads to an obligation for other members to act militarily. The US as an ally with the most powerful army in NATO is expected to be the first in line to defend other member states. Macron's doubts about the US entering a war to assist other NATO members is one of many reasons why he often speculates on creating common European forces to replace the North Atlantic alliance in Europe in an event of NATO's dissolution. However, Macron's doubts stem from the fact that today's Europe and United States do not share a common vision, a consensus on the direction in which they are headed, and that for the first time America has a president who does not share the same idea of the European project, as the leaders of Western Europe..$^{53}$ And even if Trump is not re-elected for the second term, different historical forces are pulling the old allies apart. For his own reasons, Macron, similarly to Trump, has a genuine mistrust in NATO as an organisation and almost explicitly suggests that it constitutes a problem in itself, rather than a solution, and perhaps even endangers Europe. At a meeting with NATO Secretary General Jens Stoltenberg, he openly challenged the militant Russophobic rhetoric of NATO officials, including Stoltenberg himself:

"Is our enemy today Russia, as I sometimes hear? Is it China? Is it the goal of NATO to designate them as enemies? I don't believe so. Our common enemy today is terrorism, which has hit each of our countries" ${ }^{\prime 2}$.

The international consensus which allowed the Balkan elites to push the non-NATO countries of the region, i.e. Serbia and Bosnia-Herzegovina, into NATO is dissipating. Macron might not favour this outcome, but he is certainly aware of its possibility. Perhaps that was why he wanted to be the first to declare that (1) the EU membership prospect for the Balkan countries is not an option in the foreseeable future, and (2) that NATO would not be able to exist, function and operate in the current format and that a new alternative European military alliance should emerge on the ruins of old NATO. However, Stoltenberg's strong support for the Ukraine, bordering membership invitation, as well as his statements that Georgia would certainly join the alliance, show the level of what could be described as desperation within the NATO ranks ${ }^{55}$. If the al-

\footnotetext{
52 Emmanuel Macron warns Europe: NATO is becoming brain-dead (interview). 2019. The Economist. URL: https:// www.economist.com/europe/2019/11/07/emmanuel-macron-warns-europe-nato-is-becoming-brain-dead (accessed 20.04.2020).

${ }^{53}$ Assessing Emmanuel Macron's apocalyptic vision. 2019. The Economist. URL: https://www.economist.com/leaders/2019/11/07/assessing-emmanuel-macrons-apocalyptic-vision (accessed 20.04. 2020).

${ }^{54}$ Macron Says: "Russia, China Not NATO Allies Common Enemies - Terrorism Is". Radio Free Europe. URL: https://www.rferl. org/a/macron-says-russia-china-not-nato-allies-common-enemies---terrorism-is/30297520.html (accessed 20.04. 2020).

${ }_{55}$ Doorstep statement by NATO Secretary General Jens Stoltenberg ahead of the meeting of NATO Ministers of Foreign Affairs. NATO website. URL: https://www.nato.int/cps/en/natohq/opinions_171016.htm?selectedLocale=en (accessed 22.04. 2020).
} 
liance accepts these two countries as its members, it will most certainly not be ignored by Moscow. On the other hand, that would mean that NATO may be ready to risk European and world peace only to demonstrate a reason for its existence. Trump and the part of US establishment backing him would hardly let this happen. These conflicting perspectives by the key players in the West point to conclusion that the dissolution of NATO may not be just a fantasy. At least, the ways in which it operates now is almost certainly jeopardised.

For a number of reasons, the Balkans and particularly the 'Serb question' may substantially contribute to harming NATO's long-term unity and stability. In an extreme scenario, the alliance's dissolution might be a culmination of ideological conflict in the political West and a turning point in a search for a new consensus.

\title{
About the authors:
}

Stevan Gajić - PhD (Political Sci.), Scientific Associate, Institute of European Studies. Trg Nikole Pašića 11, 11000 Belgrade, Serbia. E-mail: office@ies.rs.

Elena G. Ponomareva - Dr. of Science (Political Sci.), Professor of Comparative Politics Department, Moscow State Institute of International Relations (University). 76 Prospect Vernadskogo, room 3026, Moscow, Russian Federation, 119454. E-mail: nastya304@mail.ru.

\section{Conflict of interests:}

The authors declare absence of conflict of interests.

\section{Ускорение экспансии НАТО}

на Балканах как следствие

\section{евро-атлантических противоречий}

\author{
С. Гайич, Е. Пономарева \\ DOI 10.24833/2071-8160-2020-2-71-70-93
}

Институт европейских исследований, Белград, Сербия

Московский государственный институт международных отношений (Университет)

Аннотация: Крушение биполярного мира для стран пост-югославского пространства как и всех Балкан ознаменовалось усилением геополитического влияния Запада. С самого начала межнациональной войны в Югославии в 1991 г., за которой уже в 1992 г. последовало признание западными грандами сепаратистских республик, европейские 
государства, США и НАТО активно участвовали в балканском кризисе. Дипломатов, финансовых и политических советников в процессе разрушения СФРЮ довольно быстро сменили военные: в 1994-1995 гг. НАТО осуществляла бомбардировки сербских позиций в Боснии и Герцеговине, а в 1999 г. агрессии со стороны альянса подверглось суверенное государство, член $\mathrm{OOH}$ - Союзная республика Югославия. Такое поведение было в логике однополярности или провозглашенного Дж. Бушем-ст. нового мирового порядка, в котором «нет альтернативы американскому лидерству».

С 2008 г. мир вступил в эпоху перемен, масштабы и последствия которых сравнимы с описанными в книге Пола Кеннеди «Взлет и паление великих держав». Грузия, напав на Южную Осетию, перешла «красную линию» внешней политики России, вынудив последнюю проявить державные амбиции; Китай продемонстрировал свои претензии на мировое лидерство масштабными символами и победами Олимпиады; крах американского рынка недвижимости спровоцировал глобальный экономический кризис, а поддержка Брюсселем и Вашингтоном идеи независимости косовских албанцев создала опасный международно-правовой прецедент. К началу 2020 г. много проблем накопилось и у ЕС на фоне продолжающегося миграционного кризиса активизировались правые и националистические движения, усилились разногласия между членами. Задолго до появления COVID-19 серьёзным стресс-тестом для экономики и социальной структуры Евросоюза стал Brexit. Параллельно драматические события развивались по другую сторону Атлантики: победа убеждённого антиглобалиста Д. Трампа в борьбе за президентское кресло в 2016 г. стала шоком для нео- и ульталиберального крыла американского истеблишмента. Таким образом, были поколеблены и оспорены «правила игры», установленные в период однополярности (1991-2008). Впоследствии идеологический консенсус, сформировавший на Западе после окончания Холодной войны, в результате роста внесистемных политических движений, направленных не только против расширения ЕС, но и против него самого, был ещё в большей мере поставлен под сомнение.

Роль и значение названных событий для Балкан удивительны и парадоксальны. Несмотря на очевидное ослабление своих позиций, глобалисты не отказались от атлантической интеграции оставшихся вне рамок НАТО балканских стран. В разгар пандемии 27 марта 2020 г. Северная Македония стала 30 членом альянса, пройдя ради этого унизительную процедуру изменения названия страны. Тремя годами ранее в НАТО приняли Черногорию, население которой не имело возможности высказаться по этому вопросу на референдуме. Переговоры Белграда и Приштины по «нормализации отношений», наступление на права Республики Сербской, инициатива Хорватии по проекту Междуморья и многие другие подобные усилия являются этапами процесса натоизации бывшей Югославии. На основе анализа большого корпуса нарративных источников и новейшей литературы в статье представлены основные тенденции и возможные перспективы развития Балкан, зависящие от исхода продолжающейся на Западе идеологической и политической борьбы.

Ключевые слова: Балканы, расширение НАТО, Россия, Сербия, ЕС, албанский вопрос

\section{Об авторах:}

Стеван Гайич - PhD (политические науки), научный сотрудник Института европейских исследований, Белград, Сербия. Trg Nikole Pašića 11, 11000 Belgrade, Serbia.

E-mail: office@ies.rs.

Елена Георгиевна Пономарева - профессор, доктор политических наук, профессор кафедры сравнительной политологии МГИМО МИД России. Россия, 119454, Москва, проспект Вернадского, 76. E-mail: nastya304@mail.ru.

\section{Конфликт интересов:}

Авторы заявляют об отсутствии конфликта интересов. 


\section{References:}

Bajrović R., Garčević V., Kraemer R. 2018. Hanging by a Thread: Russian's strategy of destabilization in Montenegro. Philadelphia: Foreign Police Research Institute. URL: https://www.fpri. org/wp-content/uploads/2018/07/kraemer-rfp5.pdf

Borinski P. 2002. NATO Towards Double Enlargement: The Case of the Balkans. Journal of European Integration, vol. 24, no. 2, pp. 113-136.

Brzezinski Z. 2016. The Grand Chessboard: American Primacy and Its Geostrategic Imperatives. New York: Basic Books.

Cascone G. 2010. NATO enlargement and the Western Balkans in NATO in Search of a Vision. Georgetown University Press. Pp. 175-200.

Chodakiewicz M.J. 2012. Intermarium: The Land between the Black and Baltic Seas, New Brunswick-New Jersey: Transaction Publishers.

Cooper R. 2004. The Breaking of Nations: Order and Chaos in the Twenty-First Century. London: Atlantic Books.

Fukuyama F. 1992. The End of History and the Last Man. New York: Free Press.

Gardner H. 2019. IR Theory, Historical Analogy, and Major Power War, Cham: Palgrave Macmillan.

Graham T.E., Levitsky J.E., Munter C.P. \& Wisner F.G. 2018. Time for Action in the Western Balkans: Policy Prescriptions for American Diplomacy. New York: National Committee on American Foreign Policy \& East-West Institute. URL: https://www.eastwest.ngo/sites/default/ files/Time-for-Action-in-the-Western-Balkans.pdf

Huntington S. 1996. The Clash of Civilization and the Remaking of Word Order. New York: Simon \& Schuster.

Jović D. 2018. Accession to the European Union and perception of external actors in the Western Balkans. Croatian International Relations Review, vol. 24, no. 83, pp. 6-32.

Kennedy P. 1987. The Rise and Fall of the Great Powers: Economic Change and Military Conflict from 1500 to 2000. New York: Random House.

Kissinger H. 1994, Diplomacy. New York: Simon \& Schuster.

Lampe J.R. 2013. Yugoslavia's foreign policy in Balkan perspective: Tracking between the superpowers and non-alignment. East Central Europe, 40(1-2), pp. 97-113.

Less T. 2016. Dysfunction in the Balkans: Can the Post-Yugoslav Settlement Survive? Foreign Affairs. December 20. URL: https://www.foreignaffairs.com/articles/bosnia-herzegovina/2016-12-20/dysfunction-balkans

Majumdar M. 2017. Newly Declassified Documents: Gorbachev Told NATO Wouldn't Move Past East German Border. The National Interest. URL: https://nationalinterest.org/blog/ the-buzz/newly-declassified-documents-gorbachev-told-nato-wouldnt-23629 (accessed 22.12. 2019).

Marusic D., Bedenbaugh S., Wilson D. 2017. Balkans Forward: A New US Strategy for the Region. Washington: Atlantic Council. URL: http://cd.bos.rs/online-citanka-novi-lideri--novemogucnosti-10/uploaded/Balkans_Forward_web_1128.pdf

Mitrović A. 2004. Време нетрпетивих: политичка историја великих држава Европе, 1919-1939 [The Age of the Intolerant: Political History of the Great European Powers, 19191939]. Podgorica: CID. (In Serb.)

Morrison K. 2017. The trajectory and parameters of democratic transition in Montenegro. Building Democracy in the Yugoslav Successor States: Accomplishments, Setbacks, and Challenges since 1990. Cambridge University Press. 
Mulchinock N. 2017. NATO and the Western Balkans: From Neutral Spectator to Proactive Peacemaker in NATO and the Western Balkans: From Neutral Spectator to Proactive Peacemaker. Palgrave Macmillan. Pp. 1-293.

Ponomareva E. G. 2020. Quo vadis, Serbia? Russia in Global Affairs. no. 1 January/March. DOI: 10.31278/1810-6374-2020-18-1-158-179.

Ponomareva E., Frolov A. 2019. Agressiya NATO protiv Yugoslavii: mezhdunarodno-pravovye, voenno-strategicheskie i geopoliticheskie posledstvi [NATO Aggreshion against Yugoslavia: international-leagal, military strategic and geopolitical consequences]. MGIMO Review of International Relations. no. 2(65). pp. 32-56. DOI: 10.24833/2071-8160-2019-2-65-32-56 (In Russ.)

Rakovic A. 2017. Montenegro from secession to NATO: reflection on the disorientation of the russian foreign policy (2006-2017). National interest, vol. 28, no 13, pp. 69-86. (In Serbian)

Vishnyakov Y., Ponomareva E. 2018. Serbiya na Balkanah: izobretenie "porohovogo pogreba Evropy» [Serbia in the Balkans: The Invention of 'Europe's Gun Powder Magazine']. Contemporary Europe, no. 7, pp. 108-121. DOI: http://dx.doi.org/10.15211/soveurope72018115129 (In Russ.)

\section{Литература на русском:}

Вишняков Я.В., Пономарева Е.Г. 2018. Сербия на Балканах: изобретение «порохового погреба Европы». Современная Европа. № 7. С. 108-121. http://dx.doi.org/10.15211/ soveurope72018115129

Пономарева Е.Г., Фролов А.В. 2019. Агрессия НАТО против Югославии: международно-правовые, военно-стратегические и геополитические последствия. Вестник МГИМО-Университета. №. 2(65), С. 32-56. https://doi.org/10.24833/2071-8160-2019-2-65$32-56$ 